\title{
Productivity of polyclonal minigarden and rooting of Handroanthus heptaphyllus Mattos minicuttings
}

\author{
Produtividade de minijardim multiclonal e enraizamento de \\ miniestacas de Handroanthus heptaphyllus Mattos
}

\author{
Taiane Pires de Freitas de Oliveira ${ }^{1 *}$; Deborah Guerra Barroso ${ }^{2}$; Kelly Ribeiro \\ Lamônica $^{3}$; José Geraldo de Araújo Carneiro ${ }^{2}$; Marcos André de Oliveira ${ }^{1}$
}

\begin{abstract}
Aiming the improvement of the quality of techniques related to the growth of "ipê-roxo" cuttings, this study had as objective to evaluate the productivity of Handroanthus heptaphyllus Mattos ministumps and the rooting capacity of the minicuttings in successive collections in the presence and absence of exogenous auxin. Seedlings were grown in $280 \mathrm{~cm}^{3}$ tubes with selected different sources of seeds. At 141 days after the sowing, seedlings were pruned at $8 \mathrm{~cm}$ from the collar with the goal to establish the minigarden. The productivity of ministumps over successive collections as well as the need to apply indol-3-butiric acid on the roots of the minicuttings were evaluated. Eight collects of minicuttings were carried out, at three, five, six, seven, eight, nine, 10 and 11 months after the pruning. In each of those cycles the number of minicuttings were quantified per mini-stump. Before their staking in $180 \mathrm{~cm}$ ${ }^{3}$ tubes, half of the minicuttings from each cycle were treated with $8000 \mathrm{mg} \mathrm{L}^{-1}$ of Indole-3-Butiric Acid (IBA) (2 seconds). The ministumps tolerated the pruning (with $100 \%$ survival); over $70 \%$ of the ministumps produced minicuttings along all the time in each collection cycle. A cyclical behavior in the minigarden was observed with higher productivities of the ministumps at 8 and 11 months after pruning of seedlings. The use of IBA stimulated more robust root systems of the cuttings, although this was not a condition for rooting.
\end{abstract}

Key words: Ministumps, indol-3-butiric acid, ipê-roxo

\section{Resumo}

No intuito de aprimorar as técnicas para a produção de mudas de ipê-roxo, visando à qualidade, este estudo tem como objetivo avaliar a produtividade de minicepas de Handroanthus heptaphyllus Mattos e a capacidade de enraizamento das miniestacas em coletas sucessivas na presença e na ausência de auxina exógena. As plântulas produzidas a partir de sementes foram cultivadas em tubetes de $280 \mathrm{~cm}^{3}$. Aos 141 dias após a semeadura, as mudas foram podadas a $8 \mathrm{~cm}$ da base, com o objetivo de estabelecer o minijardim. A produtividade das minicepas em sucessivas coletas, bem como a necessidade de se aplicar o ácido indol-3-butírico no enraizamento das miniestacas foram avaliadas. Oito coletas de miniestacas foram realizadas, em três, cinco, seis, sete, oito, nove, 10 e 11 meses após a poda. Em cada um destes ciclos, o número de miniestacas foi quantificado por minicepa. Antes do estaqueamento em tubetes de $180 \mathrm{~cm}^{3}$, metade das miniestacas de cada ciclo foi tratada com $8000 \mathrm{mg} \mathrm{L}^{-1}$ de ácido indol-3-butírico

\footnotetext{
1 Discentes, Universidade Estadual do Norte Fluminense Darcy Ribeiro, UENF, Campos dos Goytacazes, RJ, Brasil. E-mail: ibitaiane@hotmail.com; marcosagronoliveira@bol.com.br

2 Profs., Universidade Estadual do Norte Fluminense Darcy Ribeiro, UENF, Campos dos Goytacazes, RJ, Brasil. E-mail: deborah@ uenf.br; carneiro@uenf.br

3 Prof., Instituto Federal de Educação, Ciência e Tecnologia do Tocantins, IFTO, Colinas do Tocantins, TO, Brasil. E-mail: krlamonica@gmail.com

* Author for correspondence
} 
(AIB) por 2 segundos. As minicepas toleraram a poda (com 100\% de sobrevivência), mais de $70 \%$ das minicepas produziram miniestacas ao longo do tempo em cada ciclo de coleta. Um comportamento cíclico no minijardim foi observado com maiores produtividades das minicepas aos 8 e 11 meses após a poda das mudas. $\mathrm{O}$ uso de AIB estimulou sistemas radiciais mais robustos nas miniestacas, embora esta não seja uma condição para o enraizamento.

Palavras-chave: Minicepa, ácido indolbutírico, ipê-roxo

\section{Introduction}

Brazilian forestry is almost exclusively directed to species of Pinus and Eucalyptus genera, with use of genetically improved seedlings for Pinus and cuttings for Eucalyptus to meet industrial needs.

The demand for forestry techniques with regard to native species is derived primarily from the need to maintain the established Permanent Preservation Areas, to restoration of the Legal Reserve Area in each rural property (BRASIL, 2012) and to recover degraded areas. However, there is also an economic demand for the use of these species; this demand has been met in recent years by exploiting remainder forest fragments. The numerous native species with high commercial value include Handroanthus heptaphyllus Mattos, a deciduous species in the Bignoniaceae family commonly known as ipê-roxo, ipê-rosa, ipeúna, or pau d'arco. Due to the intense exploitation of the regions where it naturally grows, this species has been identified for restoration works in forest ecosystems and also for landscape purposes (GEMAQUE; DAVIDE; FARIA, 2002). This species is commonly propagated through seeds; however, the seeds vary in viability when stored what reduces their germination percentage (CARVALHO, 1994). Vegetative propagation is an alternative for propagating species that show viability reductions along the seed storage or insufficient seed production; however, there are no reports in the literature concerning this studied species under all silvicultural aspects.

Tree propagation may be carried out by using several techniques. The method is defined according to the objective, species, genotypic characteristics of the parent plant, types of propagules, time of year (WENDLING; FERRARI; DUTRA, 2005) and rooting capacity. Among the techniques used to multiply forest species on a large scale, minicutting is a technique that consists of using part of sprouts (mini-cuttings) from plants propagated by ministumps (ALFENAS et al., 2004) and pruning by removing the part of the sprouts.

In Brazil, the use of mini-cutting is the most widely employed technique to propagate species of the genus Eucalyptus primarily because this method combines the quality of the grown cuttings and lower production costs (MAFIA et al., 2005).

This technique is also viable for species such as Cedrela fissilis (XAVIER et al., 2003), Erythrina falcata (WENDLING; FERRARI; DUTRA, 2005), Pinus taeda (ALCANTARA et al., 2007), Grevillea robusta (SOUZA JUNIOR; QUOIRIN, WENDLING, 2008), and Toona ciliata (SILVA et al., 2012; SOUZA et al., 2014).

With regard to ipê-roxo, Freitas (2012) tested increasing doses of IBA $(0,2000,4000,6000$, and $8000 \mathrm{mg} \mathrm{L}^{-1}$ ) and found that, although it may not stimulate rooting, $8000 \mathrm{mg} \mathrm{L}^{-1}$ showed that cuttings with higher first-order root lengths and also higher number of second-order roots, promoted a more robust root system to resist stress conditions in the planting areas.

Therefore, there are important techniques that can improve the ipê-roxo cuttings production in quality and quantity in short time. It is also relevant to take into consideration the environmental and economic importance of ipê-roxo, to reduce the anthropic pressure on the remainder forests, to preserve species. This study has as objective to evaluate the productivity of Handroanthus heptaphyllus Mattos ministumps and the rooting capacity of the minicuttings in successive collects in the presence and absence of exogenous auxin. 


\section{Material and Methods}

The experiment was set up in a greenhouse covered with polypropylene $(150 \mu \mathrm{m})$ and shade $(30 \%)$ at the State University of North Fluminense Darcy Ribeiro (Universidade Estadual do Norte Fluminense Darcy Ribeiro; UENF) in Campos dos Goytacazes, RJ, (Brazil) at a latitude of $21^{\circ} 19^{\prime} 23^{\prime \prime}$ (S) and longitude of $41^{\circ} 19^{\prime} 41^{\prime \prime}(\mathrm{W})$. To establish the multiclonal garden, the seedlings were grown from Handroanthus heptaphyllus seeds collected from parents located in the UENF campus.

The sowing was carried out in $280-\mathrm{cm}^{3}$ polypropylene tubes filled with the substrate Basaplant florestal ${ }^{\circledR}$ and the slow-release fertilizer (Osmocote $\left.{ }^{\circledR} 14-14-14\right)$ at a concentration of $8 \mathrm{~g} \mathrm{Kg}^{-}$ ${ }^{1}$. Two seeds were sowed in each tube. A thinning was performed at 30 days when the plantlets showed 2 pairs of leaves. The most vigorous and centralized plantlets in each tube were kept in the containers.

\section{Establishment, management, and monitoring of the} multiclonal minigarden

At 141 days after the sowing, the height and collar diameter were measured, following the sprouts were pruned at $8 \mathrm{~cm}$ from the collar to form the ministumps; as consequence the multiclonal minigarden was established which supplied the mini-cuttings. Two pairs of leaves were left in each pruned seedling in opposite sides to stimulate photosynthesis and facilitate the growth of new sprouts. Expecting the reduction competition for light, thereby avoiding etiolation, 27 ministumps were placed in each 54-cell tray, a total of 112 ministumps each $\mathrm{m}^{2}$ of the trays. The trays were arranged on suspended wooden benches in a greenhouse covered with plastic (i.e., 150- $\mu \mathrm{m}$ agricultural film) and $30 \%$ shade.

The length of the new sprouts growth indicated the timing of the ministumps collects, when the length of most of them reached at least $5 \mathrm{~cm}$. Eight samples were collected at $3,5,6,7,8,9,10$, and
11 months after the top pruning of the seedlings. After each cycle the number of minicuttings were quantified per mini-strain.

Reaching the minimum height, the sprouts from the ministumps were collected using pruning shears preserving at least one axillary bud at the pruning point so that new sprouts could grow and be quantified in the next cycle.

The production cycle was defined as the period between the sprouts collects in the minigarden to the final quality evaluation of the cuttings at 4 months.

During the management of the ministumps, fertilizations were added weekly with $20 \mathrm{~mL}$ of complete nutrient solution per minigarden during the first 2 months after the pruning. The Bolles Jones (1954) nutrient solution was used with the following composition: $\mathrm{N}=8 \mathrm{mmol} \mathrm{L}^{-1}(37.5 \%$ $\left.\mathrm{NH}_{4}^{+}\right) ; \mathrm{P}=1 \mathrm{mmol} \mathrm{L}^{-1} ; \mathrm{K}=3 \mathrm{mmol} \mathrm{L}{ }^{-1} ; \mathrm{Ca}=2 \mathrm{mmol}$ $\mathrm{L}^{-1} ; \mathrm{Mg}=1.25 \mathrm{mmol} \mathrm{L}^{-1} ; \mathrm{S}=3.75 \mathrm{mmol} \mathrm{L}^{-1} ; \mathrm{Cl}=20$ $\mathrm{mmol} \mathrm{L}{ }^{-1} ; \mathrm{Fe}=9 \mathrm{mmol} \mathrm{L}^{-1} ; \mathrm{B}=6.6 \mathrm{mmol} \mathrm{L}{ }^{-1} ; \mathrm{Mn}=$ $10 \mathrm{mmol} \mathrm{L}^{-1} ; \mathrm{Zn}=1 \mathrm{mmol} \mathrm{L}^{-1} ; \mathrm{Cu}=1 \mathrm{mmol} \mathrm{L}{ }^{-1}$; and $\mathrm{Mo}=0.3 \mathrm{mmol} \mathrm{L}-1$.

The ministumps showed symptoms of nitrogen deficiency approximately 2 months after the end of the application of this solution. Therefore, $10 \mathrm{~mL}$ of an ammonium sulfate solution $\left(\left[\mathrm{NH}_{4}\right]_{2} \mathrm{SO}_{4}\right)$ was applied at a concentration of $8 \mathrm{~g} \mathrm{~L}^{-1}$ weekly on each mini-strain. Pests and diseases in the minigarden were monitored along the experiment.

Data of the mini-strain collects were submitted to a descriptive analysis. Furthermore, Pearson's correlations were used to establish the relationship between productivity and the biometric characteristics of the ministumps.

\section{Rooting of the minicuttings}

Half of the collected minicuttings grown in each cycle were treated with IBA $\left(8000 \mathrm{mg} \mathrm{L}^{-1}\right)$, and the other half was staked without applying the plant growth regulator with the goal to evaluate the 
benefits with regard to the root growth of the ipêroxo mini-cutting (FREITAS, 2012).

The treatments were carried out according to the completely randomized design (CRD) and a $6 \times 2$ factorial scheme (6 growth cycles and 2 doses of IBA) with 4 replicates composed of 10 minicuttings per plot in the first 2 cycles and 12 in the others.

The minicuttings were then placed in a misting chamber with a $150-\mu \mathrm{m}$ polypropylene plastic cover under intermittent misting with 15 -second sprays every 15 minutes to control the humidity for root growth.

The survival of the minicuttings was evaluated 30 days after the staking at the end of the dispatch from the rooting sector. Four cuttings per plot were evaluated with regard to the number of first-order and second-order roots, the length of the first-order roots, and the dry mass of the root system. For this evaluation, all excess substrate was removed with water using sieves to retain the roots. The length of the roots was measured using a ruler. To evaluate the dry mass, the root system of the minicuttings was placed in paper bags and put in a convection oven at $65^{\circ} \mathrm{C} \pm 2$ for 72 hours for subsequent weighing on an analytic scale.

The data counting, results were logged $(x+1)$, and the percentage data were transformed using $(\mathrm{X}+1)^{1 / 2}$. Finally, the variance and the means data were compared using Tukey's test at $\alpha=.05$ (ZIMMERMANN, 2004).

\section{Results and Discussion}

\section{Survival of the ministumps}

A survival rate of $100 \%$ of the ministumps was observed after 8 mini-cutting collect cycles.
This percentage indicates that the species tolerates pruning and successive collections, thereby making the use of this system possible for cuttings production.

Souza et al. (2014) and Silva et al. (2012) found similar results using minigardens of Australian Red Cedar (Toona ciliata) evaluated in tubes after 4 successive mini-cutting collects. In addition, Xavier et al. (2003), Cunha, Wendling and Souza Júnior $(2005,2008)$ also found $100 \%$ survival rates for (via minicuttings from minigardens in tubes) of Cedrela fissilis after 4 collects Eucalyptus benthamii, after 5 collects and Erythrina falcata after 8 collects, respectively. Titon et al. (2003) found a mini-cutting survival rate above $98 \%$ after 8 collections from Eucalyptus grandis from minigardens in tubes. According to Souza Junior, Quoirin and Wendling (2008), a mini-cutting survival rate above $90 \%$ is common in minigardens for many species when appropriate management and efficient mineral nutrition.

\section{The productivity of the multiclonal minigarden}

The first quantification and seedling cutting was achieved at 3 months (after the seedling pruning) when they were at least $5 \mathrm{~cm}$ height and showed an average productivity of 1.76 minicuttings per mini-strain. This quantity was attributed to the possible stress caused to the seedlings as a result of the pruning and the presence of buds that did not grow as a result of apical dominance (Figure 1). Continuous production began in the second cycle after adjusting for nutrition with an average of 1.98 minicuttings per mini-strain. 
Figure 1. The productivity of Handroanthus heptaphyllus ministumps in tubes over successive mini-cutting collects beginning in May 2011 after the pruning of the seedlings at 3 months and the average monthly temperatures recorded during the experiment. The vertical bars indicate the confidence intervals $\left(\mathrm{CI}_{95 \%}\right)$.

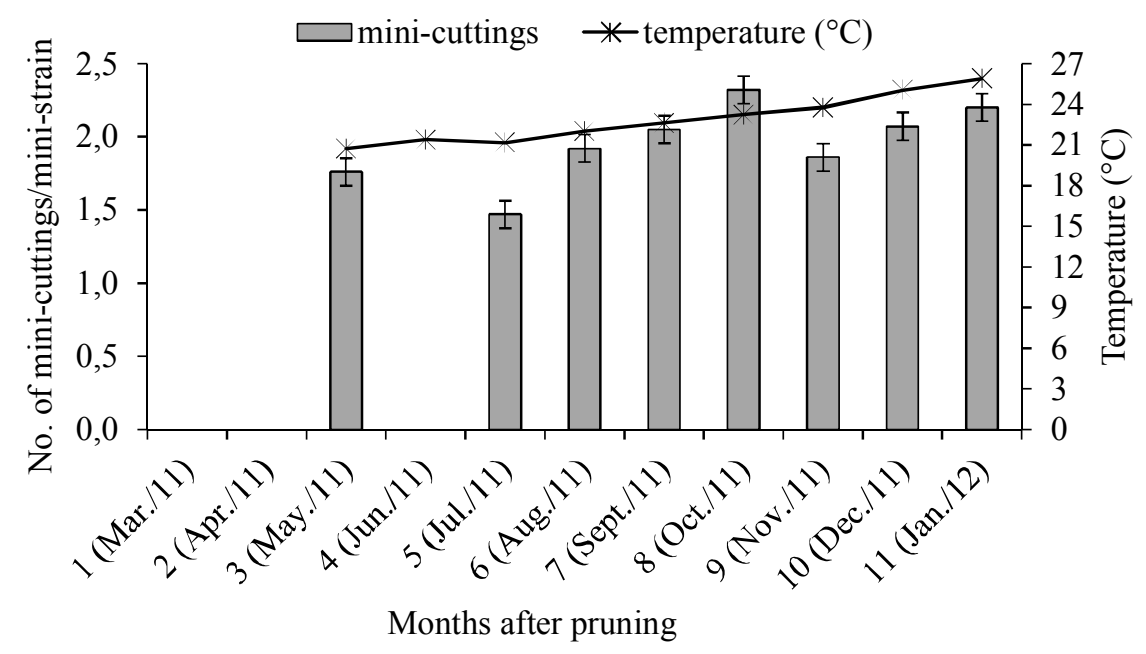

Source: Elaboration of the authors.

According to Wendling and Souza Júnior (2003), after the first pruning and the consequent break of the apical dominance, an adaptation period occurs in the ministumps that subsequently reorganize the orthotropic growth system into a plagiotropic growth system. Therefore, the dormant buds become active after the first collect, thereby resulting in higher growth stimulation. This period of time varies as a function of the species and climatic conditions.

During the minigarden management, more than $70 \%$ of the 197 ministumps produced minicuttings in each collect cycle, reaching an average monthly production of 1.42 minicuttings per ministump.

Xavier et al. (2003) found an average productivity of 1.3 minicuttings per mini-strain per collect in 30day intervals in a Cedrela fissilis minigarden also established in tubes. Wendling, Xavier and Titon (1999) obtained an average productivity of 1.9 minicuttings per ministrain of Eucalyptus grandis in each collection during a 20-day interval in a tube system, too. Ferreira et al. (2010) found an average productivity of 1.9 minicuttings per ministump of Sapium glandulatum after 4 collects carried out only once per season. Therefore, the average monthly productivity was 0.63 minicuttings per ministump.
In 7 collects Altoe et al. (2011) found averages of $3.18,3.55$, and 3.03 sprouts per ministump with Psidium guineense (Brazilian guava), Psidium cattleyanum (Peruvian guava), and Psidium guajava cv. Paluma (guava), respectively, grown in tubes. The intervals between collects were 49, 95, 130, 166, 229, 347 and 397 days.

Approximately 4 months after the pruning, the ministumps showed symptoms of nitrogen deficiency that might have reduced the growth speed and the number of minicuttings grown in the second cycle ( 1.47 minicuttings per ministumps) at 5 months after the top pruning. This result differs from those of the other cycles (Figure 1).

According to Souza et al. (2014), nitrogen and potassium were the most extracted nutrients by australian cedar ministumps during the collects periods in both grown systems (tubes and duct channels). So, it is necessary to fertilize minigardens, to keep high productivity levels of ministumps along the collects. Ferreira et al. (2012) studied Toona ciliata in a duct channel system and observed an initial reduction in the sprout growth of the ministumps. The author observed a recovery of the minigarden after applying a nutrient solution. On 
the other hand, Souza Junior, Quoirin and Wendling (2008), reported that temperature reduced the tube minigarden productivity of Grevillea robusta.

Wendling, Xavier and Titon (1999) found oscillations in the productivity of mini-garden of the hybrids of Eucalyptus spp. and attributed this result to changes in temperature. Temperature might have influenced the growth of sprouts, promoting reduction in-the production of vegetative propagules in some tropical species (ROSA et al., 2009). This author took into account that winter induces bud dormancy with the reduction or avoiding the stimulation of sproutings (GATTI, 2002). However, this present study cannot state that temperature influenced the growth of sprouts given that there are not well-defined seasons in this region.

In the following cycles, the minigarden production occurred monthly. This cyclical behavior increased productivity up to the 5 th cycle (2.32) at 8 months after the pruning; however, the next cycle showed a reduction (1.86), but a subsequent increase in productivity was observed in the last 2 cycles that produced an average of 2.07 and 2.2 minicuttings per mini-strain, respectively. This growth may be attributed to a temporary exhaustion of the mini-strain that favored a reduction in sprout production. This exhaustion was the result of the pruning intensity and the reduction in the amount of carbohydrates. Titon et al. (2003) also reported that the exhaustion of the micro- and ministumps caused the cyclical behavior observed in the Eucalyptus grandis minigardens over 8 collects.

Gatti (2002) observed an oscillation from 1.1 to 2 minicuttings per Tectona grandis mini-strain in a tube minigarden along 6 collects. The author studied 30 day intervals pointed out a monthly average of 1.7 ministump. The results converge to those found in the present study. For jequitibá (Cariniana estrellensis), Gatti et al. (2011) also found an average of 3.9 minicuttings per ministump in 3 monthly collects.

The average productivity was 185.3 minicuttings throughout the collect cycles with a density of 112 ministump per $\mathrm{m}^{2}$. This distribution over time is shown in Figure 2. The maximum production was observed 8 months after the pruning with 245.6 minicuttings per $\mathrm{m}^{2}$ followed by 221.2 minicuttings per $\mathrm{m}^{2}$ at 11 months after the pruning.

Figure 2. The productivity of the Handroanthus heptaphyllus multiclonal minigarden at different mini-cutting collects periods.

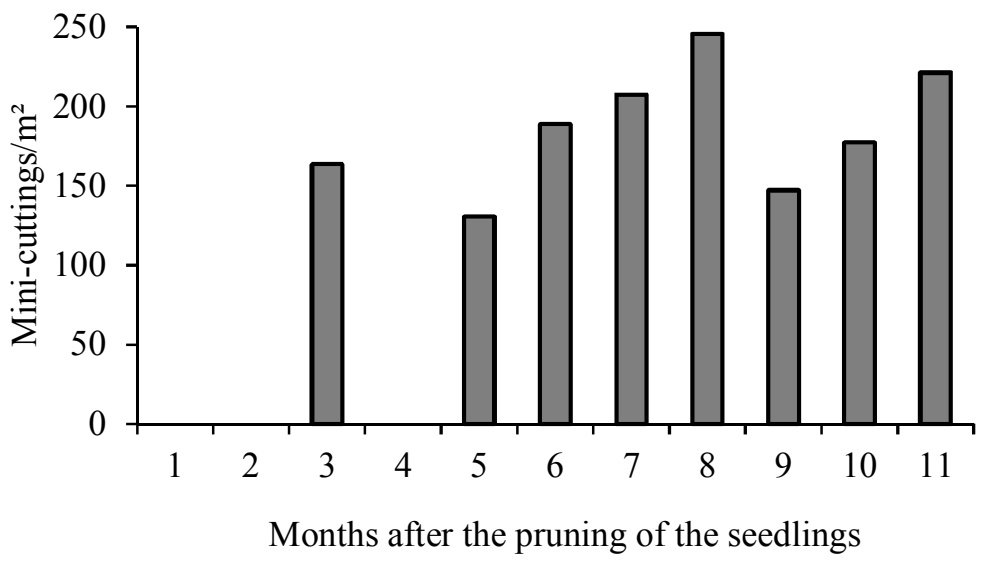

Source: Elaboration of the authors. 
Studying the minicutting technique of Sapium glandulatum, Ferreira et al. (2010) found higher productivity values than those found in the present study, with 582 and 609 minicuttings per $\mathrm{m}^{2}$ in spring and summer, respectively. Ferriani et al. (2011) found high mini-cutting production in Piptocarpha angustifolia that varied between 113.4 and 259.2 minicuttings per $\mathrm{m}^{2}$ in winter and spring, respectively. Souza et al. (2014) obtained lower results regarding to the present study when studying a minigarden system in tubes, finding an average productivity of 113 minicuttings per $\mathrm{m}^{2}$ every 31 days, with a density of 112 ministumps per $\mathrm{m}^{2}$ of nursery.

Table 1 shows the correlations among the number of minicuttings produced per mini-strain and the heights and diameters of the seedlings that formed the minigarden.

Table 1. Pearson's correlations among the number of minicuttings per mini-strain of Handroanthus heptaphyllus produced in 8 collects from the minigarden in tubes and the height and diameter of the seedlings that formed the minigarden.

\begin{tabular}{lc}
\hline & Total mini-cuttings/mini-strain \\
\hline Height $(\mathrm{cm})$ & $0.2377^{*}$ \\
Diameter $(\mathrm{mm})$ & $0.1854^{*}$ \\
\hline
\end{tabular}

197 observations; *significant according to a t-test at $\alpha=.05$. Source: Elaboration of the authors.

Despite the significant data, these correlations were low and ranged from 18.5 to $23.8 \%$. Theseresults indicate that the initial biometric characteristics of the seedlings and the minicuttings act independently (Table 1). These results corroborate those of Silva et al. (2012), who also found low correlations for Toona ciliata in minigarden systems using duct channels and tubes.

\section{Rooting of the minicuttings}

The survival percentage of minicuttings was above $80 \%$ regardless of treatment in evaluating the effect of the mini-cutting collect cycles and the 2 concentrations of IBA on the dispatch time from the rooting sector at 30 days after the staking (Table 2 ). These results match the percentage of acceptable losses for forest nurseries what suggest that this method is technically viable.

In contrast to the results verified in this study, Alcantara et al. (2008) found that the mortality of the minicuttings increases in Pinus taeda after using IBA at a concentration of $1000 \mathrm{mg} \mathrm{L}^{-1}$. The low survival rate when using IBA shows probable toxicity for this species due to the eventual possibility that this auxin stimulates rooting until a certain concentration. Besides that concentration it shows an inhibiting effect. However, thoses responses vary among species and genetic material. However, Titon et al. (2003) studied 2 clones (CC1 and CC8) and 2 hybrids (CC11 and CC12) of Eucalyptus grandis and observed higher survival for the clone $\mathrm{CC} 1$ relative to the control sample at IBA doses of 1000, 2000, and $4000 \mathrm{mg} \mathrm{L}^{-1}$.

With regard to the root system quality, Table 2 shows that the number and length of the first-order roots, the number of the second-order roots, and the dry mass of the roots showed similar behavior. The highest averages were found when the cuttings were submitted to IBA immersion. The minicuttings collected 6 months after the pruning stimulated a larger number and longest length of first-order roots and a highest root dry mass, with average values of $6.97,30.2$, and 0.092 , respectively. The average number of second-order roots varied among the cycles. The lowest number of cuttings was observed 
in the 5th cycle (16.1 roots) compared with the 2nd and 3rd cycles (Table 2). The IBA application influenced the percentage of rooting; however, differences were found between the cycles, with a reduction in the last cycle $(53.2 \%)$. The minicutting roots were directly linked to climatic conditions, the amount of carbohydrates stored in the parent, and the increased content of inhibitors present in the parents. High levels of reserves and high carbon/ nitrogen ratios, favored the root formation in the cuttings (PAIVA; GOMES, 1995).

According to the studies carried out by Pereira et al. (2005), different concentrations of IBA $(0,1000$, 2000, 4000, and $6000 \mathrm{mg} \mathrm{L}^{-1}$ ) did not influence the rooting percentage of the jabuticabeira (Myrciaria jabuticaba) apical cuttings. Souza et al. (2009) demonstrated the vegetative propagation viability of australian red cedar using the mini-cutting process, regardless of the application of a growth regulator (IBA) to stimulate rooting at the tested concentrations, which resulted in $100 \%$-rooted mini-cuttings.

Problaby those species have an enough endogenous reserve of auxin to stimulate rooting. On the other hand, specie like candeia (Eremanthus erythropappus) even with using plant growth regulators showed cow rooting ability (GOULART, 2003).

Table 2. Average survival rate, number of first-order roots (NFOR), number of second-order roots (NSOR), firstorder root length (FORL), dry mass of the roots (DMR), and rooting (RTG) of the minicuttings of Handroanthus heptaphyllus at 30 days after staking with regard to the dispatch from the rooting sector and as a function of IBA application and the mini-cutting collect cycles after pruning.

\begin{tabular}{|c|c|c|c|c|c|c|c|c|c|}
\hline \multirow{3}{*}{$\begin{array}{l}\text { Collect } \\
\text { cycles }\end{array}$} & \multicolumn{3}{|c|}{ Survival (\%) } & \multicolumn{3}{|c|}{ NFOR } & \multicolumn{3}{|c|}{ NSOR } \\
\hline & \multicolumn{2}{|c|}{ IBA $\left(\mathrm{mg} \mathrm{L}^{-1}\right)$} & \multirow{2}{*}{ Average } & \multicolumn{2}{|c|}{ IBA $\left(\mathrm{mg} \mathrm{L}^{-1}\right)$} & \multirow{2}{*}{ Average } & \multicolumn{2}{|c|}{$\operatorname{IBA}\left(\mathrm{mg} \mathrm{L}^{-1}\right)$} & \multirow[t]{2}{*}{ Average } \\
\hline & 0 & 8000 & & 0 & 8000 & & 0 & 8000 & \\
\hline $1(3 *)$ & 100 & 95 & $97.5 \mathrm{a}$ & 3.35 & 5.57 & $4.42 \mathrm{ab}$ & 13.2 & 32.6 & $22.9 \mathrm{ab}$ \\
\hline $2\left(5^{*}\right)$ & 100 & 95 & $97.5 \mathrm{a}$ & 4.45 & 3.95 & $4.20 \mathrm{ab}$ & 31.7 & 45.1 & $38.4 \mathrm{a}$ \\
\hline $3\left(6^{*}\right)$ & 93.8 & 87.5 & $90.7 \mathrm{a}$ & 4.65 & 9.30 & $6.97 \mathrm{a}$ & 41.4 & 38.4 & $39.9 \mathrm{a}$ \\
\hline $5(8 *)$ & 83.3 & 85.4 & $84.4 \mathrm{a}$ & 2.80 & 4.90 & $3.85 \mathrm{ab}$ & 8.0 & 24.2 & $16.1 \mathrm{~b}$ \\
\hline $6(9 *)$ & 93.8 & 81.3 & $87.6 \mathrm{a}$ & 3.65 & 5.42 & $4.53 \mathrm{ab}$ & 19.1 & 16.1 & $17.6 \mathrm{ab}$ \\
\hline $8(11 *)$ & 81.3 & 85.4 & $83.4 \mathrm{a}$ & 2.46 & 4.42 & $3.44 \mathrm{~b}$ & 24.4 & 27.7 & $26.0 \mathrm{ab}$ \\
\hline Mean & $92.0 \mathrm{~A}$ & $88.3 \mathrm{~A}$ & & $3.6 \mathrm{~B}$ & $5.6 \mathrm{~A}$ & & $22.9 \mathrm{~B}$ & $30.7 \mathrm{~A}$ & \\
\hline $\mathrm{CV}(\%)$ & \multicolumn{2}{|c|}{5.32} & & \multicolumn{2}{|c|}{22.3} & \multicolumn{4}{|c|}{30.0} \\
\hline \multicolumn{4}{|c|}{ FORL $(\mathrm{cm})$} & \multicolumn{2}{|c|}{ DMR (g) } & & \multicolumn{2}{|c|}{ RTG (\%) } & \\
\hline $1(3 *)$ & 18.4 & 30 & $24.2 \mathrm{ab}$ & 0.037 & 0.056 & $0.047 \mathrm{~b}$ & 81.3 & 93.8 & $87.5 \mathrm{a}$ \\
\hline $2\left(5^{*}\right)$ & 21.5 & 25.2 & $23.4 \mathrm{ab}$ & 0.060 & 0.079 & $0.069 \mathrm{ab}$ & 87.5 & 87.5 & $87.5 \mathrm{a}$ \\
\hline $3\left(6^{*}\right)$ & 24 & 36.3 & $30.2 \mathrm{a}$ & 0.064 & 0.121 & $0.092 \mathrm{a}$ & 87.5 & 87.5 & $87.5 \mathrm{a}$ \\
\hline $5(8 *)$ & 7.7 & 25.4 & $16.6 \mathrm{~b}$ & 0.018 & 0.051 & $0.034 \mathrm{~b}$ & 50.0 & 87.5 & $68.8 \mathrm{ab}$ \\
\hline $6(9 *)$ & 17.6 & 14.0 & $15.8 \mathrm{ab}$ & 0.034 & 0.027 & $0.030 \mathrm{~b}$ & 93.8 & 68.8 & $81.3 \mathrm{ab}$ \\
\hline $8\left(11^{*}\right)$ & 16.7 & 25.4 & $21.0 \mathrm{ab}$ & 0.048 & 0.062 & $0.055 \mathrm{ab}$ & 50.0 & 56.3 & $53.2 \mathrm{~b}$ \\
\hline Mean & $17.7 \mathrm{~B}$ & $26.0 \mathrm{~A}$ & & $0.044 \mathrm{~B}$ & $0.066 \mathrm{~A}$ & & $75.0 \mathrm{~A}$ & $80.2 \mathrm{~A}$ & \\
\hline $\mathrm{CV}(\%)$ & \multicolumn{2}{|c|}{18.5} & & \multicolumn{2}{|c|}{51.6} & & \multicolumn{2}{|c|}{14.6} & \\
\hline
\end{tabular}

* months after the top pruning; Means followed by the same uppercase letter in the row do not differ between one another according to an F test $(\alpha=.05)$. Means followed by the same lowercase letter in the column do not differ between one another according to a Tukey's test $(\alpha=.05)$.

Source: Elaboration of the authors. 


\section{Conclusions}

Under the conditions of the experiment, the following conclusions are drawn:

The ministumps tolerated pruning given the sprouts production over time;

There was cyclical mini-strain production, with higher averages for the 5 th and 8 th collects;

The use of IBA resulted in cuttings with more robust root systems; however, this treatment may not be necessary for rooting.

The use of minicuttings in ipê-roxo requires more experiments to adjust the management technique, despite having proved to be efficient.

\section{Acknowledgment}

To Conselho Nacional de Desenvolvimento Científico e Tecnológico (CNPq) for the financial support.

\section{References}

ALCANTARA, G. B. de; RIBAS, L. L. F.; HIGA, A. R.; RIBAS, K. C. Z. Efeitos do ácido indolilbutírico (AIB) e da coleta de brotações em diferentes estações do ano no enraizamento de miniestacas de Pinus taeda L. Scientia Forestalis, Piracicaba, v. 36, n. 78, p. 151-156, 2008.

ALCANTARA, G. B. de; RIBAS, L. L. F.; HIGA, A. R.; RIBAS, K. C. Z.; KOEHLER, H. S. Efeito da idade da muda e da estação do ano no enraizamento de miniestacas de Pinus taeda L. Revista Árvore, Viçosa, MG, v. 3, n. 31, p. 399-404, 2007.

ALFENAS, A. C.; ZAUZA, E. A. V.; MAFIA, R. G.; ASSIS, T. F. Clonagem e doenças do eucalipto. Viçosa: Editora UFV, 2004. 442 p.

ALTOE, J. A.; MARINHO, C. S.; TERRA, M. I. C.; BARROSO, D. G. Propagação de araçazeiro e goiabeira via miniestaquia de material juvenil. Bragantia, Campinas, v. 70, n. 2, p. 312-318, 2011.

BOLLES JONES, E. W. Nutrition of Hevea brasiliensis I. Experimental methods. Journal Rubber Research International Malaya, Kuala Lumpur, v. 14, p. 183-207, 1954.

BRASIL. Lei n 12.651, de 25 de maio de 2012. Institui o novo código florestal. Diário Oficial [da] República Federativa do Brasil, Brasília, 28 maio 2012, Seção 1, p. 1. 8. Veto no D. O. 28 maio 2012, p. 16. 17.

Espécies florestais brasileiras: recomendações silviculturais, potencialidades e uso da madeira. Colombo: Embrapa, 1994. 640 p.

CUNHA, A. C. M. C. M.; WENDLING, I.; SOUZA JÚNIOR, L. Miniestaquia em sistema de hidroponia e em tubetes de Corticeira-do-mato. Revista Ciência Florestal, Santa Maria, v. 18, n. 1, p. 85-92, 2008.

Produtividade e sobrevivência de minicepas de Eucalyptus benthamii Maiden et Cambage em sistema de hidroponia e em tubete. Revista Ciência Florestal, Santa Maria, v. 15, n. 3, p. 307-310, 2005.

FERREIRA, B. G. A.; ZUFFELLATO-RIBAS, K. C.; WENDLING, I.; KOEHLER, H. S.; NOGUEIRA, A. C. Miniestaquia de Sapium glandulatum (Vell.) Pax com o uso de ácido indolbutírico e ácido naftaleno acético. Revista Ciência Florestal, Santa Maria, v. 20, n. 1, p. 1931. 2010.

FERREIRA, D. A.; BARROSO, D. G.; SILVA, M. P. S.; SOUZA, J. S.; FREITAS, T. A. S.; CARNEIRO, J. G. A. Influência da posição das miniestacas na qualidade de mudas de cedro australiano e no seu desempenho inicial no pós-plantio. Revista Ciência Florestal, Santa Maria, v. 22, n. 4, p. 715-723, 2012.

FERRIANI, A. P.; ZUFFELLATO-RIBAS, K. C.; HELM, C. V.; BOZA, A.; WENDLING, I. Produção de brotações e enraizamento de miniestacas de Piptocarpha angustifólia. Pesquisa Florestal Brasileira, v. 31, n. 67, p. 257-264. 2011.

FREITAS, T. P. Propagação de ipê-roxo (Handroanthus heptaphyllus Mattos) por miniestaquia. 2012. Dissertação (Mestrado em Produção Vegetal) - Universidade Estadual do Norte Fluminense Darcy Ribeiro, Campos dos Goytacazes.

GATTI, K. C. Propagação vegetativa de pau mulato (Calycophyllum spruceanum (Benth) K. Schum.), Jequitibá (Cariniana estrellensis (Raddi) Kuntze) e teca (Tectona grandis Linn. F.) por miniestaquia. 2002. Tese (Doutorado em Ciência Florestal) - Universidade Federal de Viçosa, Viçosa, MG.

GATTI, K. C.; GONÇALVES, R. C.; XAVIER, A.; PAIVA, H. Propagação vegetativa de Jequitibá (Cariniana estrellensis (Raddi) por miniestaquia. Temas Agrarios, Montería, v. 16, n. 2, p. 54-63, 2011.

GEMAQUE, R. C. R.; DAVIDE, A. C.; FARIA, J. M. $\mathrm{R}$. Indicadores de maturidade fisiológica de sementes de ipê-roxo (Tabebuia impetiginosa (Mart.) Standl.). Revista Cerne, Lavras, v. 8, n. 2, p. 84-91, 2002. 
GOULART, P. B. Desenvolvimento de metodologia para enraizamento de estacas de candeia (Eremanthus erythropappus (DC) MacLeish). 2003. Monografia (Graduação em Engenharia Florestal) - Universidade Federal de Lavras, Lavras.

MAFIA, R. G.; ALFENAS, A. C.; FERREIRA, E. M.; ZARPELON, T. G.; SIQUEIRA, L. Crescimento de mudas e produtividade de minijardins clonais de eucalipto tratados com rizobactérias selecionadas. Revista Árvore, Viçosa, MG, v. 29, n. 6, p. 843-851, 2005.

PAIVA, H. N.; GOMES, J. M. Propagação vegetativa de espécies florestais. Viçosa: Imprensa Universitária, 1995. $40 \mathrm{p}$.

PEREIRA, M.; OLIVEIRA A. L. de; GONÇALVES, A. N.; ALMEIDA, M. de. Efeitos de substratos, valores de $\mathrm{pH}$, concentrações de AIB no enraizamento de estacas apicais de jabuticabeira [Myrciaria jabuticaba (Vell.) O. Berg.]. Scientia Forestalis, Piracicaba, n. 69, p. 84-92, 2005.

ROSA, L. S.; WENDLING, I.; GROSSI, F.; REISSMANN, C. B. Efeito da dose de nitrogênio e da formulação de substratos na miniestaquia de Eucalyptus dunnii Maiden. Revista Árvore, Viçosa, MG, v. 33, n. 6, p. 1025-1035, 2009.

SILVA, M. P. S.; BARROSO, D. G.; SOUZA, J. S.; FERREIRA, D. A.; CARNEIRO, J. G. A. Enraizamento de miniestacas e produtividade de minicepas de cedro australiano manejadas em canaletões e tubetes. Revista Ciência Florestal, Santa Maria, v. 22, n. 4, p. 703-713, 2012.

SOUZA JUNIOR, L.; QUOIRIN, M.; WENDLING, I. Miniestaquia de Grevillea robusta A. Cunn. a partir de propágulos juvenis. Revista Ciência Florestal, Santa Maria, v. 18, n. 4, p. 455-460, 2008.
SOUZA, J. C. A. V.; BARROSO, D. G.; CARNEIRO, J. G. A.; TEIXEIRA, S. L.; BALBINOT, E. Propagação vegetativa de cedro australiano (Toona ciliata $\mathrm{M}$. Roem) por miniestaquia. Revista Árvore, Viçosa, MG, v. 33, n. 2, p. 205-213, 2009.

SOUZA, J. S.; BARROSO, D. G.; SILVA, M. P. S.; FERREIRA, D. A.; GRAVINA, G. A.; CARNEIRO, J. G. A. Produtividade de minicepas de cedro australiano e remoção de nutrientes pela coleta sucessiva de miniestacas. Revista Ciência Florestal, Santa Maria, v. 24, n. 1, p. 71-77, 2014.

TITON, M.; XAVIER, A.; REIS, G. G.; OTONI, W. C. Eficiência das minicepas e microcepas na produção de propágulos de clones de Eucalyptus grandis. Revista Árvore, Viçosa, MG, v. 27, n. 5, p. 619-625, 2003.

WENDLING, I.; FERRARI, M. P.; DUTRA, L. F. Produção de mudas de corticeira-do-mato (Erythrina falcata Bentham) por miniestaquia a partir de propágulos juvenis. Colombo: Embrapa Florestas, 2005. 5 p. (Comunicado técnico, 130).

WENDLING, I.; SOUZA JÚNIOR, L. Propagação vegetativa de erva-mate (Ilex paraguariensis Saint Hilaire) por miniestaquia de material juvenil. In: CONGRESSO SUL-AMERICANO DA ERVA-MATE, FEIRA DO AGRONEGÓCIO DA ERVA-MATE, 3., 2003, Chapecó. Anais... Chapecó: Epagri, 2003. 8 p.

WENDLING, I.; XAVIER, A.; TITON, M. Miniestaquia na silvicultura clonal de Eucalyptus. Revista Folha Florestal, Viçosa, n. 1, p. 16-17, 1999.

XAVIER, A.; SANTOS, G. A.; WENDLING, I.; OLIVEIRA, M. L. Propagação vegetativa de cedro-rosa por miniestaquia. Revista Árvore, Viçosa, MG, v. 27, $\mathrm{n}$. 2, p. 139-143. 2003.

ZIMMERMANN, F. J. P. Estatística aplicada à pesquisa agrícola. Santo Antônio de Goiás: EMBRAPA Arroz e Feijão, 2004. 400 p. 